\title{
The Problem of the Unicity of Truth in the Early Oxford Franciscan School
}

\begin{abstract}
This paper examines the closely related treatments of the unicity of truth in Robert Grosseteste, Richard Rufus of Cornwall, and Thomas of York. Its focus is on their use of logical notions in their treatments, notably Grosseteste's and York's use of the notions of supposition and signification, and Rufus' use of the notion of analogy. Although at first appearance Grosseteste and York appear to posit, and Rufus to deny, a plurality of truths, I suggest this apparent disagreement is more verbal than substantive.
\end{abstract}

\section{Introduction}

That there is just one truth (veritas), the supreme truth, is proposed in numerous passages in patristic authors, notably Augustine, and was defended by Anselm in his treatise De veritate. Yet there are also many passages in patristic authors, and in both Augustine and Anselm themselves, suggesting there are many truths (veritates). ${ }^{1}$ Resolving this apparent conflict seems to have been an important motivation for the medieval thinkers I consider here to take up the question of the unicity of truth.

An adequate resolution must retain the idea that there is a single supreme truth, the eternal Word, which plays a special role in regard to truth, while also making sense of talk about a plurality of truths. In this paper my concern is to survey just one aspect of the treatment of this issue in three thinkers, namely their use of logical notions in their attempts to meet this desideratum.

The thinkers I will consider are Robert Grosseteste, Richard Rufus of Cornwall, and Thomas of York. Grosseteste (c.1168-1253) was the first lecturer to the Oxford Franciscans, from 1229/30 until 1235, when he was made Bishop of Lincoln. Although

\footnotetext{
1 As Thomas of York notes; see Thomae Eboracencis Sapientiale Liber Sextus (Sapientiale) 6.25, in Reality and Truth in Thomas of York, ed. John P.E. Scully, 3 vols ( $\mathrm{PhD}$ dissertation, University of Toronto, 1960), vol. 2, pp. 365-66: 'Ipse Anselmus, qui probare videtur unitatem veritatis, multas distinguit veritates singularum exprimens proprietates. Sapiens etiam Augustinus duplicem distinguit veritatem in libro suo De mendacio.' A new edition of the Sapientiale is currently under preparation at the Thomas Institut under the direction of Fiorella Retucci, but at this point in time book 6 is only available in Scully's edition. For an excellent account of conflicting authorities regarding the unicity of truth and the theories of Anselm and Grosseteste and their relationships, see Travis James Cooper, One Truth or Many Truths? Two Medieval Accounts of Truth: Anselm of Canterbury and Robert Grosseteste (PhD dissertation, The Catholic University of America, 2012).
} 
never a Franciscan himself, Grosseteste left a deep impression on English Franciscans, both in personal example and thought. ${ }^{2}$

Rufus (fl. 1231-56) lectured on Aristotle's works on natural philosophy and metaphysics in Paris from the early 1230s until 1238. He was one of the most important figures in the early reception of these works in the Latin West. In 1238 Rufus renounced his career as a secular master and joined the Franciscan order in Paris. He left Paris for Oxford to make his profession and to study theology. In 1256 he became the fifth Franciscan lecturer to the Oxford Franciscans. Preceding Rufus in 1253 as the fourth Franciscan lecturer at Oxford was Thomas of York. From 1256 until his death (possibly c.1260), York was the sixth Franciscan lecturer at Cambridge. ${ }^{3}$

The question of the unicity of truth is treated by all three authors. Grosseteste devoted a treatise De veritate to it, probably written at Oxford between c.1225 and the early 1230 s. ${ }^{4}$ This seems to be the first extensive treatment to follow Anselm's. Rufus considers it in book 1 of his early and short questions commentary on the Metaphysics, the Memoriale in Metaphysicam (MMet; c.1231-34); and in book 1 of a subsequent large exposition-plus-questions commentary on the Metaphysics, the Scriptum in Metaphysicam (SMet; c.1237-38). Later, now a Franciscan, Rufus considers the issue in the prologue to his Oxford lectures on the Sentences (SOx; c.1250), and in book 1, distinction 8 of his Paris lectures on the Sentences (SPar; c.1253). ${ }^{5}$ York treats the topic in book 6, chapter 25

2 For Grosseteste's biography and relations to the Franciscans, see James McEvoy, Robert Grosseteste (Oxford: Oxford University Press, 2000), pp. 19-30, 51-61.

3 For Rufus' biography, see Peter Raedts, Richard Rufus of Cornwall and the Tradition of Oxford Theology (Oxford: Clarendon Press, 1987), pp. 1-19; Rega Wood, 'Richard Rufus of Cornwall,' in A Companion to Philosophy in the Middle Ages, ed. Jorge J.E. Gracia and Timothy B. Noone (Malden, MA; Oxford: Blackwell, 2003), pp. 579-87. For York, see Fiorella Retucci, 'The Sapientiale of Thomas of York, OFM: The Fortunes and Misfortunes of a Critical Edition,'Bulletin de philosophie médiévale 52 (2010), pp. 133-59, and references therein.

4 Robert Grosseteste, De veritate, in Die philosophischen Werke des Robert Grosseteste, Bischofs von Lincoln 1235-1253, ed. Ludwig Baur (Münster i. W.: Aschendorfsche Verlagsbuchhandlung, 1912), pp. 130 -43. For a volume of new editions of Grosseteste's theological and philosophical opuscula I am preparing with Cecilia Panti and Pietro Rossi, I am making a new edition of De veritate, and in quotations below I occasionally indicate significant changes to Baur's edition.

5 The works of Richard Rufus of Cornwall are being edited by the Richard Rufus of Cornwall Project, of which I am a member, under the direction of Rega Wood. In quotations from Rufus I use the following sources.

1. Memoriale in Metaphysicam (MMet), ed. Rega Wood and Neil Lewis, 2013 (http://rrp.stanford. edu/MMet.shtml). 2. Scriptum in Metaphysicam (SMet). This work survives in a longer redaction containing exposition of Aristotle's text and questions, and a shorter redaction with most of the questions but no exposition. The text of the questions does not vary significantly between the two redactions. Quotations from such questions (indicated by Q in the section numberings below), all taken from books 1 or 5, are from the edition of the shorter redaction published on the Richard Rufus Project website (http://rrp.stanford.edu/works.shtml). Parts of the longer redaction not present in the shorter are quoted from the manuscript Salamanca, Biblioteca Universitaria, Biblioteca General Histórica 2322 (=S) and employ section numberings to be used in our edition. The Rufus Project expects to publish the first of two volumes containing an edition of this work in the near future. In the introduction 
of his massive philosophical summa, the Sapientiale. We do not know when York commenced this work, but it remained unfinished. ${ }^{6}$

How are the treatments of truth in these works related? There is no indication that Rufus used Grosseteste's De veritate in MMet or SMet. SOx and SPar by contrast show clear use of De veritate, as does York's Sapientiale. The Sapientiale draws also from SMet. ${ }^{7}$ There is closely parallel material on truth in the Sapientiale and SOx, ${ }^{8}$ but the direction of borrowing remains to be determined, given uncertainty over the dating of the Sapientiale. SPar borrows material from SOx.

\section{Two Preliminaries}

In speaking of the unicity of truth, the word 'truth' renders veritas. No one doubted there are many vera, that is, things that are true. That there is a supreme truth (veritas), identified with God or more particularly, the eternal Word, is also not in dispute. The question is whether there are other truths (veritates) besides this by which true things are true. The fact that there are many true things does not settle this issue. Our authors all mention Anselm's point that although there are many simultaneous temporal items, there is only one time. The question is whether the supreme truth is related to true things in an analogous way. To avoid confusion, I will henceforth always use the word 'truth' to translate veritas and 'true thing' or 'item' to translate verum.

A second preliminary point concerns what sort of truth is at issue. Medieval thinkers apply the term 'true' to quite different kinds of things. Therefore we must consider the possibility that the debate over the unicity of truth is intended to concern only the truth of some, but not all true things. Now the most important distinction among true things is between propositions or proposition-like items in the soul what are often called compositions and divisions - and extra-mental things. The

\footnotetext{
to this edition we defend our view that this work was written at Paris c.1237-38. Timothy B. Noone, by contrast, argued that it was written at Oxford in the 1240s; see 'Richard Rufus of Cornwall and the Authorship of the Scriptum super Metaphysicam,' Franciscan Studies 49 (1989), pp. 55-91.

3. Lectures on the Sentences of Peter Lombard. Quotations from the Sententiae Oxonienses (SOx) are from the manuscript Oxford, Balliol College 62 (= B); those from the Sententiae Parisienses (SPar) are from the manuscript Vatican, Bibl. Apost. Vat. Lat. 12993 (= V). For a full list of manuscripts containing Rufus' works, see http://rrp.stanford.edu/manuscripts.shtml.

6 York, Sapientiale 6.25, ed. Scully, pp. 361-79.

7 This claim and the claim that there is no indication of use of Grosseteste's De veritate in SMet are defended in the introduction to the edition of the Scriptum in preparation by the Richard Rufus of Cornwall Project.

8 In particular, in the treatment of the question whether truth exists, a question not taken up in Rufus' Metaphysics commentaries. See York, Sapientiale 6.24, ed. Scully, pp. 348-51, and SOx Prologue (B, fol. 9va).
} 
truth of these is often called complex and non-complex truth respectively. Although contemporary analytic philosophers tend to reserve the term 'truth' for complex truth, this was not so in medieval authors. Indeed, a conception of non-complex truth and true things had a long history preceding the Middle Ages. ${ }^{9}$ It is certainly present in all three authors considered here.

There is no doubt that in their treatments of the unicity of truth, our authors have in mind non-complex truth. It is less clear whether complex truth is also at issue. I'm inclined to think it is, but this raises additional issues I can't go into given limits of space, and so I shall leave this issue unresolved here.

In their attempts to meet the desideratum mentioned above our authors employ ideas drawn from the logical theories of their day. It is on this aspect of their treatments that I focus in this paper. Grosseteste and York propose similar views, with York's being an elaboration of Grosseteste's. Their basic point is that the supreme truth is in some way always signified or predicated when we speak of truth, and yet expressions such as 'every truth' or 'truths' stand for, or 'supposit', many truths, and thus there are many truths. Rufus holds that 'truth' is a name said analogically or multiply. Whenever we use the name 'truth', there is some sort of indirect reference to the supreme truth. This is because when we speak of other truths, they are not truths in the strictest or an unqualified sense. Instead, they are called truths because they bear a certain kind of relationship to what is truth in a strict and unqualified sense, the supreme truth. All three authors therefore take some sort of indirect reference to the supreme truth to be involved in our talk of truth, but Grosseteste and York hold that there are also other truths, while Rufus says that although we may speak of other truths, they are not truths in a strict and unqualified sense. I will propose in the last part of this paper that despite this verbal difference and their appeal to different logical notions of their day, these authors are in substantive agreement.

\section{Robert Grosseteste}

One of Grosseteste's chief reasons to reject the unicity of truth is given at the start of De veritate in the first pro-argument he gives for a plurality of truths. He notes that if there is no truth other [than the supreme truth], then truth is one and singular and does not admit distribution or plurality, so that we may say "every truth" or "many truths". ${ }^{10}$ And yet, Grosseteste notes, in the Gospel [John 16:13] we read: He will teach you every truth. Despite the various theological authorities and arguments

9 See Timothy B. Noone, 'Truth, Creation, and Intelligibility in Anselm, Grosseteste, and Bonaventure,' in Truth: Studies of a Robust Presence, ed. Kurt Pritzl (Washington D.C.: Catholic University of America, 2010), pp. 102-26.

10 Grosseteste, De veritate, ed. Baur, p. 130: 'Si enim nulla est alia veritas, tunc veritas est unica et singularis nec recipit distributionem aut pluralitatem, ut dicatur "omnis veritas", aut "multae veritates”. Sed e contra in Evangelio legitur: Ipse docebit vos omnem veritatem.' 
pro and con subsequently considered, it is this point that Grosseteste expressly provides later in the text as his reason for rejecting the unicity of truth.

At the very start of De veritate, then, Grosseteste introduces logical considerations into his treatment of the unicity of truth. The same holds for his account of the nature of truth in general. Since this account plays an important role in York's treatment of unicity, a brief overview is appropriate.

Grosseteste starts this account by considering truth as it is considered in logic, noting that we are most accustomed to speak of the truth of a spoken declarative sentence (oratio enuntiativa). From an account of the truth of declarative sentences, he spins out an all-embracing account of truth, complex and non-complex, created and uncreated, which he takes to be equivalent to Anselm's definition of truth as 'rectitude perceptible by the mind alone.' Now the truth of a spoken declarative sentence,

as a philosopher says, is nothing other than so to be in the thing signified as speech says. And this is what others say: that truth is the adequation of speech and thing, and the adequation of things and thoughts. ${ }^{11}$

Grosseteste takes the first definition ${ }^{12}$ to be extensionally equivalent to the definition of truth in terms of adequation, a conception new in his day. ${ }^{13}$ Whether he proposes one or two definitions in terms of adequation is unclear. Thomas of York takes these to be two distinct definitions. ${ }^{14}$ Possibly Grosseteste treats them as equivalent, or per-

11 Grosseteste, De veritate, ed. Baur, p. 134: 'Sicut dicit philosophus, non est aliud, quam ita esse in re signata, sicut dicit sermo. Et hoc est, quod alii <aliqui Baur> dicunt veritatem esse "adequationem sermonis et" rei et "adequationem rerum et intellectuum" <et adaequationem ad intellectum Baur>.' See also Grosseteste, De veritate propositionis, in Die philosophischen Werke des Robert Grosseteste, ed. Baur, p. 144: 'Veritas enim sermonis vel opinionis est adaequatio sermonis vel opinionis et rei. Haec autem adaequatio nihil aliud est, quam ita esse in re, sicut sermo vel opinio dicit;' and Dictum 21, British Library, MS Royal 6.E.v, fol. 14vb: 'Veritas est adaequatio sermonis et rei, cum scilicet res est sicut dicitur. Praecipua itaque veritas est adaequatio sive correspondentia vel conformitas rerum summo sermoni, hoc est Verbo Patris aeterno.'

12 Although one might expect a reference to philosophus in this context to be to Aristotle, Grosseteste perhaps has in mind contemporary or earlier logicians, or perhaps their glosses on Aristotle, since his first definition is much closer to what we find in Abelard than in Aristotle (Categories 5.4a35; Metaphysics 4.7.1011b25). See Peter Abelard, Glossae super 'Peri hermenias' 9, ed. Klaus Jacobi and Christian Strub, Corpus Christianorum Continuatio Mediaevalis 206 (Turnhout: Brepols, 2010), p. 253: 'Omnis enim propositio uera dicitur, quia ita est in re, ut proponit.'

13 On the history of use of the notion of adequation to define truth in the Latin West, see Philotheus Boehner, 'Ockham's Theory of Truth,' Franciscan Studies 5 (1945), pp. 138-61. As Boehner notes, the earliest uses seem to be by Philip the Chancellor and William of Auxerre. Philip the Chancellor, Summa de bono 1.0.2, 2 vols, ed. Nikolaus Wicki (Bern: Francke, 1985), vol. 1, p. 10. William of Auxerre, Summa aurea 1.9.3, 7 vols, ed. Jean Ribaillier, Spicilegium Bonaventurianum, 16-20 (Paris: Editions du Centre National de la Recherche Scientifique; Grottaferrata: Editiones Collegii S. Bonaventurae, 1980 - 87), vol. 1, p. 195.

14 York, Sapientiale 6.27, ed. Scully, p. 404: 'Si ad signum, tunc est illa definitio Boethii: Veritas est adaequatio sermonis et rei seu signi et signati. Si respectu intellectus, igitur est illa definitio Isaaci: 
haps as two parts of a single definition, because he treats adequation as a symmetric relation and treats thought as a kind of inner speech.

Indeed, Grosseteste goes on to note that inner speech, namely the thought expressed by vocal speech, is truer than outer or vocal speech, for outer speech is an expression of inner speech. ${ }^{15}$ Now if there is inner speech that is not just adequated to things but is its own adequation to them, it will not just be true, but will itself be truth. But this is how it is with the speech or Word of the Father. It is not just adequated to what it says, but is adequation itself and so is truth.

According to Grosseteste, not only may speech be adequated to things, but things may also be adequated to speech, and thus true. Considering the adequation of things to speech, he notes that there will be a conformity, or adequation, of things said by the Word to the Word, or more particularly to their rationes in the Word. This conformity is their rectitude and obligation to be what they are. And since a thing is true to the extent that it is as it ought to be, "the truth of things is their being as they ought to be and their rectitude and conformity to the Word by whom they are eternally said.' Since this sort of rectitude is perceptible only by the mind, Anselm correctly defined truth as 'rectitude perceptible by the mind alone' - a definition applying both to a rectifying rectitude, the Word, and to a rectified rectitude, the truth of things. ${ }^{16}$

The truth of created things, then, is their conformity to their rationes in the eternal Word. But this raises a problem. Since each created thing necessarily conforms to its ratio, this account seems to find no place for falsity. In particular, propositions belong to the created realm, and so they too will be in conformity to their rationes in the eternal Word, and so must be true. But of course, propositions can be, and often are, false.

Veritas est adaequatio rerum et intellectuum.' York's attributions to Boethius and Isaac (Israeli) are both incorrect. It is noteworthy that the oldest manuscript containing Grosseteste's De veritate, Oxford, Lincoln College, 54, copied around the end of Grosseteste's lifetime, simply contains the first definition in terms of adequation. The second oldest manuscript (XIV ${ }^{1}$ ), Oxford, Exeter College 28, contains the text I substituted in note 11 above for the text Baur printed, which he based on a single late and very low-quality manuscript. It is in fact possible that Grosseteste provided only the first definition in terms of adequation and that Lincoln College, 54 transmits the correct text.

15 Grosseteste, De veritate, ed. Baur, p. 134.

16 Grosseteste, De veritate, ed. Baur, pp. 134-35: 'In rebus autem, quae dicuntur hoc aeterno Sermone, est conformitas ipsi sermoni, quo dicuntur. lpsa quoque conformitas rerum ad hanc aeternam dictionem est earum rectitudo et debitum essendi, quod sunt. Recta enim est res et est ut debet, inquantum est huic Verbo conformis. Sed inquantum est res ut debet, intantum vera est. Igitur veritas rerum est earum esse prout debent esse, et earum rectitudo et conformitas Verbo, quo aeternaliter dicuntur. Et cum haec rectitudo sit sola mente perceptibilis et in hoc distinguatur a rectitudine corporali visibili, patet, quod convenienter definitur ab Anselmo veritas cum dicit, eam esse rectitudinem sola mente perceptibilem. Et complectitur haec definitio etiam summam veritatem, quae est rectitudo rectificans simul cum veritatibus rerum, quae sunt rectitudines rectificatae.' 
Grosseteste solves this problem by distinguishing between a thing's first and second being. ${ }^{17}$ The first being of a thing is its essential nature; the second being is its perfection. Something cannot lack first being if it exists, but it can lack second being. Thus the ratio of a thing in the Word seems to specify not just its essential nature an ought-to-be it cannot fail to accord with - but also its perfection, an ought-to-be it can fail to accord with. Therefore every proposition will be a true proposition in that it asserts or denies something of something, for in doing so it will conform to its ratio in the Word, since it is the first being of a proposition to do this. But at the same time a proposition may be false, in not conforming to its ratio, if things are not as it signifies them to be, since for things to be as it signifies is a proposition's second being or perfection. What we ordinarily call a true proposition is true in both ways. So too, a human being will be true inasmuch as she is composed of body and soul, but a false human being if she is vicious or mendacious. Grosseteste takes this account to be equivalent to treating the truth of a thing as fullness of being (plenitudo essendi). In this way he links this account up to the idea that truth is being, an idea expressed in Augustine's formula that truth is id quod est.

In response to the question whether there is only one truth Grosseteste returns to the initial pro-argument and the semantics of the name 'truth'.

We also think, as Augustine suggests in his book On Lying, that the truth of things is multiple, otherwise the name 'truth' would not admit plurality or distribution. (For simply the relation of one thing to many does not make that one thing many, any more than the relation of one time to many simultaneous temporal things makes that one time many times, for there are not many simultaneous times. In the same way, if there were only the supreme truth, which in itself is just one, on account of the relation of that one [truth] to many things, many things could be true, just as there simultaneously are many temporal things. But there would not on account of this be many truths, any more than many simultaneous times.) For a plural name or one distributed by means of a universal sign requires many supposits. Accordingly, we could not say 'many truths' or 'every truth' unless there were many truths supposited. Therefore in such expressions the truths of things are supposited, these [truths] being conformities to the reasons of the things in the eternal truth. But perhaps the name 'truth' is used nowhere without signifying the supreme truth as the form of the name in some way, at least adjacently or obliquely. For just as the truth of a thing can be understood only in the light of the supreme truth, so perhaps neither is it supposited by the name 'truth' except with signification of the supreme truth. There is therefore a single truth everywhere signified and predicated by this name 'truth', as Anselm maintains, but in the many truths of things that one truth is called many truths. ${ }^{18}$

17 Grosseteste, De veritate, ed. Baur, pp. 135-36. See also Anselm, De veritate 2, in S. Anselmi Cantuariensis archiepiscopi opera omnia, 2 vols, ed. Franciscus Salesius Schmitt (Edinburgh: Nelson, 1940 - 51), vol. 1, pp. 169-99.

18 Grosseteste, De veritate, ed. Baur, pp. 138-39: 'Putamus etiam, sicut innuit Augustinus in libro de mendacio, multiplicem esse rerum veritatem. Alioquin non susciperet nomen veritatis pluralitatem et distributionem. Unius enim ad multa sola comparatio non facit illud unum multa, sicut comparatio unius temporis ad plura temporalia, quae simul sunt, non facit illud multa tempora. Non enim sunt multa tempora simul. Similiter, si non esset veritas nisi summa, quae in se est unica propter collationem illius unius <nominis Baur> ad multa, possent esse multa vera, sicut simul sunt multa tem- 
Here Grosseteste notes that the fact that there are many true things does not, as such, entail that there are many truths. Instead, he defends a plurality of truths on the basis of the way plural and distributed names work. He alludes to a logical principle in his day that a name distributed by the distributive word 'omnis' requires at least three supposita ${ }^{19}$ - that is, to correctly speak of 'every truth' requires that there be at least three truths that the expression stands for or supposits. Likewise, the correct use of a plural, as in 'many truths', requires it to supposit for more than one truth.

The notion of supposition is one of two central notions from the terminist logic of Grosseteste's day. The other is that of signification. These very roughly correspond to reference and meaning. By appeal to supposition Grosseteste defends a plurality of truths, but by appeal to signification he defends a special role for the one supreme truth. These and other logical notions appear from time to time in Grosseteste's writings as parts of a presupposed conceptual framework, but are not explained. Exactly how he understands the notions of signification and supposition therefore remains unclear. But the general framework operative in his day, to which we may suppose he owes allegiance in broad outline, may be briefly presented as follows.

Signification is a fixed feature of a spoken sound. Spoken sounds are given signification when they are introduced into the language, or 'imposed', to use the technical term. William of Sherwood, writing in Paris probably c.1235-50, defines signification as 'the presentation of a form to the intellect.' ${ }^{20}$ Often to signify is also described, following Boethius' translation of Aristotle's De interpretatione, as 'to establish a thought, ${ }^{, 21}$ with a word signifying what it brings to mind in the listener as a matter of its conventional introduction. What a name signifies was typically taken in

poralia. Sed propter hoc non essent multae veritates, sicut nec multa simul tempora. Nomen enim plurale aut distributum per <per om. Baur> signum universale exigit multa supposita. Quapropter non possent dici "plures veritates", aut "omnis veritas", nisi essent multae veritates suppositae. Supponuntur ergo in talibus locutionibus veritates rerum, quae sunt conformitates rationibus rerum in aeterna veritate. Sed forte nusquam ponitur nomen veritatis, quin significet ut formam nominis aliquo modo saltem adiacenter vel oblique veritatem summam. Sicut enim veritas rei nec intelligi potest nisi in luce veritatis summae, sic forte nec supponitur per nomen veritatis nisi cum significatione veritatis summae. Unica est ergo veritas ubique significata et praedicata per hoc nomen veritas, sicut vult Anselmus, scilicet veritas summa. Sed in multis veritatibus rerum dicitur illa una veritas multae veritates.'

19 Or, as it is also often stated, three appellata, that is, presently existing things to which it applies. See for example, William of Sherwood, Syncategoremata, ed. Christoph Kann and Raina Kirchhoff (Hamburg: Felix Meiner Verlag, 2012), p. 8. Peter of Spain attributes this doctrine to Aristotle, in De caelo (1.1, 268a16-19), but rejects it on account of true propositions with 'every sun', 'every moon' or 'every phoenix'. See Tractatus called afterwards Summule Logicales (Tractatus), ed. Lambertus Marie de Rijk (Assen: Van Gorcum, 1972), pp. 213-14.

20 William of Sherwood, Introductiones in logicam, ed. Charles Lohr, Peter Kunze and Berhard Mussler, Traditio 39 (1983), p. 266 in pp. 210 -99: 'Est igitur significatio praesentatio alicuius formae ad intellectum.'

21 See E. Jennifer Ashworth, 'Signification and Modes of Signifying in Thirteenth-Century Logic: A Preface to Aquinas on Analogy,' Medieval Philosophy and Theology 1 (1991), pp. 43-50 in pp. 39-67. 
the 13th century to be a form or common nature of some sort. ${ }^{22}$ Such a form, York will expressly tell us, is what is meant by the expression 'form of the name' used above by Grosseteste.

Supposition is a property of a name as it occurs in a proposition. Unlike what it signifies, what a name supposits or stands for may vary depending on propositional context. Medieval thinkers devised a complex scheme of kinds of supposition, since propositional context can radically vary what the same name stands for. For example, in 'man is a name', the name 'man' stands for itself. In 'man is a species' it stands for what it signifies, the form of man. But in the proposition 'A man is running', the name 'man' supposits or stands for the things having that form - that is, individual human beings. As this latter case indicates, what a name supposits for typically is not the same as what it signifies. A name is said to be imposed for things for which it supposits, but to be imposed from the form it signifies, in this case, the form of man. ${ }^{23}$

In logic texts of Grosseteste's day, treatments of supposition typically focus on concrete common names, such as 'homo'. But Grosseteste's concern above is with the abstract name 'veritas' in either plural form or as distributed by 'omnis'. And he takes it as so used to supposit or stand for the truths (veritates) of things, not for the things that are true (vera). He identifies these truths with the conformities of the things to their rationes in the eternal Word. Thus in such contexts 'omnis veritas' or 'veritates' supposits for the many particular relations of adequation or conformity of things to their rationes in the Word.

As for the supreme truth, Grosseteste identifies this with the form signified by the name. He holds that "perhaps the name "truth" is used nowhere without signifying as the form of the name in some way, at least adjacently or obliquely, the supreme truth.' Here Grosseteste uses the notion of signification to account for the special role played by the supreme truth. Even so, exactly what he has in mind is unclear. His remarks suggest some hesitation, or at least, qualification in proposing this thesis. This is not so much, I think, because of his use of the word 'perhaps' (forte), used frequently in his writings as an expression of modesty, but of the words in some way, at least adjacently or obliquely (nominis aliquo modo saltem adiacenter vel oblique). ${ }^{24}$

22 I simplify, as our authors seem to do too, since often a distinction is drawn between a name's primary significate - a thought or concept in the mind - and its secondary one, the form or nature thought of.

23 See Ashworth, 'Signification and Modes of Signifying,' p. 47; Thomas Aquinas, Scriptum super libro tertio Sententiarum, 3.6.1.3, ed. R.P. Maria Fabinaus Moos (Paris: P. Lethielleux, 1933), p. 232: 'In quolibet nomine est duo considerare: scilicet id a quo imponitur nomen, quod dicitur qualitas nominis; et id cui imponitur, quod dicitur substantia nominis. Et nomen, proprie loquendo, dicitur significare formam sive qualitatem, a qua imponitur nomen; dicitur vero supponere pro eo cui imponitur.'

24 See above, n. 18. 
'Adjacently' and 'obliquely' are technical notions of medieval grammar and logic. The adverb 'obliquely' was standardly used - as we will see York and Rufus use it - to describe situations where something is mentioned, or would be perspicuously mentioned, using an oblique case, ${ }^{25}$ rather than the nominative (directe or in recto). In the present context, Grosseteste has in mind predications made using the name 'truth', holding that the supreme truth signified by 'truth' is predicated when a created item is called a truth. But the predication is not direct, but oblique. In calling it a truth, it is being said that that item is related in some way to the supreme truth, and if this were perspicuously spelled out the supreme truth would be mentioned using an oblique case. Likewise, Grosseteste's reference to the supreme truth as being signified adjacently seems to indicate that in such cases it is something distinct from, though related to that of which it is predicated. ${ }^{26}$ This is not to say that in all cases where the name 'truth' is used the supreme truth is signified in these indirect ways. In some contexts, the signification would be direct, as in 'God is truth'. Thus, Grosseteste is implying that there is a distinction between the form signified by 'truth', this in all cases being the supreme truth, and the different ways in which that form is signified in different predications of the name 'truth'.

Grosseteste relates his claim that the supreme truth is signified indirectly in the application of 'truth' to created truths to an epistemological doctrine. Towards the end of the long passage quoted above, he notes that 'just as the truth of a thing can be understood only in the light of the supreme truth, so perhaps neither is it supposited by the name ["truth"] except with signification of the supreme truth.' According to Grosseteste, as our knowledge of created truth requires the light of the supreme truth, so supposition, or reference to created truths, involves signification of the supreme truth.

Consideration of this parallel helps to forestall the objection to Grosseteste's view that it is hardly the case that all those who use the name 'truth' are aware of the supreme truth, or that it comes to mind for them, as its role as the form signified by 'truth' suggests it should. For in considering our knowledge of truth, Grosseteste holds that there are different levels of cognition, and that everyone cognizant of something true is also in some way, 'either knowingly or unknowingly, cognizant of the supreme truth itself. ${ }^{, 27}$ In particular, those who are not pure of heart are unknow-

25 As Grosseteste uses it in his Commentarius in viii libros Physicorum Aristotelis noting that motion falls obliquely in the definition of time 'tempus est numerus motus', that is, that 'motus' here is in the genitive case; see Commentarius in viii libros Physicorum Aristotelis 4, ed. Richard C. Dales (Boulder, CO: University of Colorado Press, 1963), p. 88

26 Roger Bacon, for example, mentions an objection that takes to signify adjacently to mean by a relationship to something. See his Summa grammatica, ed. Robert Steele, Opera hactenus inedita Rogeri Baconi, Fasc. 15 (Oxford: Clarendon Press, 1940), p. 81.

27 Grosseteste, De veritate, ed. Baur, p. 138: 'Nemo est igitur, qui verum aliquod novit, qui non aut scienter aut ignoranter etiam ipsam summam veritatem aliquo modo novit. Iam igitur patet, quomodo soli mundicordes summam vident veritatem et quomodo nec etiam immundi penitus eius visione frustrantur.' 
ingly cognizant of the supreme truth: it is an object of their cognition, but they do not realize this. So too, in using the term 'truth' the supreme truth comes to mind, even if the speaker or listener may not realize that it is that which comes to mind. We might well ask then what does expressly come to mind. The answer, I think, will be adequation or rectitude. So at least, York will tell us.

Grosseteste is clearly thinking of the form or nature signified by 'truth' not as a created form, but as identical with God. In his treatise De unica forma omnium, Grosseteste defends the view that God is 'form and the form of creatures. ${ }^{28}$ He relates $\mathrm{Au}$ gustine's view in De Trinitate 8.2 that God is beauty and truth, and that it is this beauty and truth that is grasped when we first hear these terms, a grasp, however, that is clouded over once we begin to inquire into them. It seems likely that in regard to other so-called transcendental names applying both to creatures and God, such as 'goodness', 'entity' or 'oneness' Grosseteste would also have held that the form from which the name is imposed in fact is the divine goodness, entity, or unity (and that these themselves, due to the divine simplicity, are God). We see hints of such a view from time to time in his writings regarding 'entity'. ${ }^{29}$

\section{Thomas of York}

Although Rufus is chronologically the next of our authors to treat the unicity of truth, ${ }^{30}$ I turn now to Thomas of York's account, since, unlike Rufus', it is an elaboration of Grosseteste's treatment. ${ }^{31}$

In particular, York examines just why in thinking of created truth we must also have in mind in some manner the uncreated truth, and makes more explicit some

28 Grosseteste, De unica forma omnium, in Die philosophischen Werke des Robert Grosseteste, ed. Baur, p. 108.

29 See his Commentarius in viii libros Physicorum 1, ed. Dales, pp. 7-8 (punctuation altered): 'Cum ergo esse de uno tantum dicatur substancialiter, et de aliis secundum dependenciam ab illo uno secundum <sed Dales> prius et posterius, manifestum est quod dicitur equivoce;' 'Si aliquid verum intellexerunt per sermonem suum hoc potuit esse: quod ens, de quocumque dicitur, non predicat ens nisi ens primum, quod ens de ente primo dicitur substancialiter; de creatis, cum dicitur esse, predicatur id idem, sed adiacenter et nuncupative.' See also, De decem mandatis 1, ed. Richard C. Dales and Edward B. King, Auctores Britannici Medii Aevi 10 (Oxford: Oxford University Press, 1987), p. 17: 'Hoc verbum sum, cum dicit Ego sum Deus, ponitur substancialiter et signat quod per se et substancialiter et necessario est, cuius comparacione alia non sunt.' For the doctrine of transcendentals in Grosseteste, including in his commentaries on the Pseudo-Dionysius, which postdate the works with which I am concerned, see Gioacchino Curiello, 'Robert Grosseteste on Transcendentals,' in Robert Grosseteste and the Pursuit of Religious and Scientific Learning in the Middle Ages, ed. Jack P. Cunningham and Mark Hocknull (Cham: Springer, 2016), pp. 189-208.

30 Assuming that Rufus' MMet postdates Grosseteste's De veritate.

31 There are close parallels between Rufus' SMet and the Sapientiale in arguments offered pro and con regarding the unicity of truth, but York's response to the problem is an elaboration of Grosseteste's view. 
of the logical elements in Grosseteste's account. One notion that is missing, however, or at least only implicit in York's account, is that of signification. Where Grosseteste distinguishes the signification and supposition of 'truth', York distinguishes the supreme truth as form and form of the name 'truth' from truth as a suppositum of 'truth'. There is just one truth as form of the name 'truth', but as Grosseteste had said, many truths supposited by that name.

Like Grosseteste, York affords the notion of adequation a central role, defining truth most generally as 'adequation, that is, rectitude.' As Grosseteste says, in the eternal Word there is adequation to the things it says, and so truth. And the Word is not just adequated, but is adequation itself, since

whatever is said of God is said in a concrete way and in an abstract way. God is not just adequated, but is adequation itself, and therefore truth. For the same reason, truth is called rectitude, since all adequation is a kind of rectitude. ${ }^{32}$

York begins his response to the question of unicity by distinguishing two kinds of form and two kinds of truth. The distinction of two kinds of truth is explicit in Grosseteste's De veritate: the supreme uncreated truth and created truth. The distinction of two kinds of form is at best implicit there, but is explicit in Grosseteste's treatise De unica forma omnium, ${ }^{33}$ and derives, as York is well aware, from Augustine, notably his De libero arbitrio voluntatis 2.16-17. According to York, form and truth are similar in that the definition 'by which a thing is that which it is' applies to both, though the name 'truth', unlike 'form', must extend to everything that exists, even matter apart from form. The two kinds of form are God, the unformed form of all things who gives form to all things, and forms formed by this form, which are the essences of things or are rooted in those essences. These formed forms vary as things themselves vary and are numbered..$^{34}$

32 York, Sapientiale 6.25, ed. Scully, pp. 372-73: 'Similiter et multo fortius <foret Scully> est in sermone interiori, id est verbo ipsius intellectus, quod ejus adaequatio cum re erit veritas. Nihilominus et hoc verum est in veritate prima, quae est in ipso Deo, immo ipse Deus. Nam si sermo interior, ut esto intellectus, esset ipsa adaequatio, tunc ipse esset veritas. In Deo autem sic est, quod propter simplicissimam essentiam quidquid dicitur de ipso dicitur concretive et abstractive; ipse est non tantum adaequatus, sed ipsa adaequatio; quare et veritas. Ex eadem ratione dicitur veritas rectitudo, quoniam omnis adaequatio rectitudo quaedam est.'

33 Grosseteste, De unica forma omnium, ed. Baur, pp. 106-11. Whether York used De unica forma is not clear. I have not found any clear sign of its use in the Sapientiale in likely places.

34 York, Sapientiale 6.25, ed. Scully, pp. 370 - 71: 'Dico igitur quod sicut est duplex forma rerum in genere, sic est duplex veritas rerum in genere. Nam forma et veritas nonnullam habent similitudinem; utrique enim convenit definitio una, quae est "qua res est id quod est," nisi quod nomen veritatis oportet extendere ad omne quod est, etiam ad materiam praeter formam (...) unde cum habeat essentiam, habet veritatem. Dico igitur quod est duplex forma rerum: Una non formata, sed omnium formossissima, sicut dicit sapiens Augustinus, De Vera Religione; et haec est Deus, qui est forma omnium, sicut ipse dicit, De Libero Arbitrio, per quem cuncta formantur, prout etiam probat in eodem. Alio modo dicitur forma rerum forma formata a forma priori, quae quidem forma secundo modo dicta est 
As for form, so for truth, York continues, 'for the first form itself is truth.' So paralleling the giver of form - the first form - and what is formed, its recipient, in the case of truth there is what is adequating, the supreme truth, and what is adequated. To explain, York adapts an analogy used by Grosseteste in De veritate to explain why nothing is seen to exist except in the supreme being. Grosseteste notes that just as water has no intrinsic shape, but is given shape by the shape of a container, so of itself a creature does not exist, but is liable to slip into non-existence. For a creature to exist is for it to be supported by the eternal Word, just as for water to have shape is for it to be shaped by its container.

York applies this analogy to adequation. He notes that in the case of water a distinction is to be made between two distinct shapes, that of the container and that of the water contained, the latter being a quality of the water produced by the container. So too we must distinguish adequation as it is in what is adequating (the supreme truth) from adequation in what is adequated. Just as the shape that is a quality of the water cannot exist without shape in the container, so 'adequation in what is adequated cannot exist without adequation in what is adequating.' Since truth is adequation or rectitude, there 'cannot be an adequated truth, which is an adequated adequation or rectified rectitude, without a rectifying and adequating rectitude and adequation. 35

In the case of water York notes that we cannot think of the shape of water without thinking of the shape of its container. Moreover, the shape of the container is obliquely predicated in the shape of what is contained. So too in the case of the names 'being' and 'truth', the first entity and first truth are predicated, but they are not principally predicated of any (created) entity or truth, but, York intimates, are predicated obliquely. ${ }^{36}$ Here too York follows Grosseteste. As we saw, in predications of 'truth' of

ipsa essentia rerum vel radicatur in ipsa, sicut superius manifestavi tibi; et haec forma variatur secundum quod ipsae res variantur et numerantur.'

35 York, Sapientiale 6.25, ed. Scully, pp. 373-74: 'Adaequatio vero dupliciter considerari potest: Ut est in adaequante et ut est in adaequato. Et adaequatio in adaequato non potest esse sine adaequatione in adaequante, sicut nec passio sine actione, nec figuratio nec in figurato sine figuratione figurante, nec sicut color illuminans sine lumine illuminante, similiter sicut nec rectitudo rectificata sine rectitudine rectificante. Unde cum veritas sit adaequatio sive rectitudo, impossible est quod sit veritas adaequata, quae est adaequatio adaequata aut rectitudo rectificata sine rectitudine et adaequatione rectificante et adaequante, sicut si poneretur aqua in vase, figuraretur figura vasis, ut esto quadrata, impossibile est aquam esse quadratum nisi per figuram continentis quadratam. Et propter hoc dicimus quod aqua sola figura continentis figuratur, quia hac sola posita, fit figura, remota, non figuratur. Et tamen in ipsa aqua est figura quae est qualitas ejus praeter figuram continentis, quae efficitur a continente; et ideo quantum ad hanc rationem, dici potest quod sola illa figura figuratur. Qualitercumque dicatur, impossibile est unam figurationem sine alia cogitare.'

36 York, Sapientiale 6.25, ed. Scully, p. 374: 'Similiter autem est de veritate; nam impossibile est aliquam creaturam subsistere nisi per conformationem veritatis primae, id est per hoc quod conformis ei supponatur in esse; alioquin in nihilum <nihil non Scully> caderet... Et ideo sicut oblique praedicatur figura continentis in figura contenti, et tamen hoc non de illa, sic in nomine essendi, et per con- 
created truths, the first or supreme truth is predicated, but obliquely and adjacently a fully perspicuous statement of the predication would involve mention of the first truth in an oblique case, reflecting the fact that when created items are called truths we are stating a relationship of them to it.

York sums up his view in these words:

I say therefore, from what has been said above, that since 'truth' is imposed from adequation, and that adequation is the form of this word 'truth', because form is that from which a name is imposed according to Aristotle, and the suppositum of this name 'truth' is that for which the name is imposed, the suppositum of this name 'truth' is multipliable. And since its supposita are all the entities, truths are numbered and multiplied as entities are numbered and multiplied. But in regard to form there is just one truth, namely the uncreated divine [truth], which is [that] to which there is the adequation of all truths. And therefore it is more truly called [truth] than every [other]. ${ }^{37}$

Here York deploys the distinction between the form from which a name is imposed and that for which it is imposed, expressly identifying the former with what Grosseteste calls the 'form of the name', and the latter with the supposita. There are many truths, because there are many supposita, but there is a single truth in regard to form, the first truth. And where Grosseteste had left it somewhat obscure exactly what he took the name 'truth' to be imposed from, York makes it clear: it is imposed from adequation. Thus, it is the form or nature adequation that the name 'truth' signifies and brings to mind. This nature is also rectitude. I suggest that when both Grosseteste and York hold that the supreme truth is the form signified by 'truth', they have in mind the point that anyone who speaks of truth has in mind the idea of how something ought to be, and thus of rectitude: 'truth' is an inherently normative notion and the norm in question just is a thing's ratio in the Word, this being identical with God himself. In thinking of a thing's truth, and thus of its ought-to-be, we are thinking, though perhaps unwittingly, of God.

sequens in nomine veritatis praedicatur ens primum et veritas prima, nec tamen de aliquo ente aut veritate principaliter ipsum ens primum aut veritas prima.'

37 York, Sapientiale 6.25, ed. Scully, p. 377: 'Dico igitur ex antedictis, quod cum veritas imponatur ab adaequatione, et illa adaequatio est forma hujus dictionis "veritas", quia forma est a qua imponitur nomen secundum Aristotelem, et suppositum hujus nominis "veritas" est cui imponitur nomen, quod suppositum hujus nominis "veritas" est multiplicabile. Et cum supposita ejus sunt omnia entia, tunc secundum quod numerantur et multiplicantur entia, numerantur et multiplicantur veritates. Quantum vero ad formam est una sola veritas, divina videlicet et increata, quae est ad quam omnium veritatum est adaequatio, et ideo dicitur omni verius, sicut superius dictum est.' 


\section{Richard Rufus of Cornwall}

Rufus first treats the unicity of truth in MMet. His brief treatment ends with the conclusion that 'there is just one truth as a principle, but many in respect of participation. ${ }^{38}$ Here Rufus speaks of many truths. In subsequent works he asserts the unicity of truth. But these works do not clash. When Rufus asserts the unicity of truth in later works, he means there is just one truth in a strict or unqualified sense, but allows that we may speak of other truths in a qualified sense. This is another way of making the point made in MMet with the qualifications 'as a principle' and 'in respect of participation'.

SMet contains a much more detailed treatment than MMet. At its end Rufus claims there is just one truth - or more precisely, that there is just one truth in the sense that there is just one truth without qualification (simpliciter). ${ }^{39}$ His argument for this conclusion that is of interest for us here is the first he gives. It is based on the idea that the concrete name 'true' (verum) is said multiply (dicitur multipliciter) of God and creatures. In his discussion later in SMet of the name 'entity', another name said multiply, Rufus describes such a name as said analogically (analogice). In his lectures on the Sentences, Rufus holds that that both the adjectival name 'true' and the abstract name 'truth' are said by analogy (per analogiam).

Rufus therefore introduces a different logical consideration into his treatment of unicity than do Grosseteste and York. They work with the notions of supposition and signification. Rufus uses the notion of a name said multiply or analogically.

Before we consider truth in more detail, it will be useful to look briefly at Rufus' treatment of entity (ens). In SMet 7 he notes that Aristotle holds that entity is said multiply and not equivocally but analogically, because it 'is said of one nature primarily, namely substance, and of others, namely accidents, derivatively (per posterius) on account of their relationship (attributionem) to substance. ${ }^{40}$ Here Rufus uses the language of Averroes' commentary as translated by Michael Scot and Aristotle's notion of pros hen equivocation..$^{41}$

38 MMet 1.2: 'Dicendum secundum opinionem Aristotelis in parte sequenti quod "unumquodque sic se habet ad veritatem ut se habet ad esse;" sed unum est quod habet esse per se et verissime; similiter una est veritas per se et verissime. Alia autem sunt quae habent esse ab illo, et sic secundario, et sic sunt aliae veritates secundario. Patet igitur quod una sola est veritas tamquam principium; multae autem secundum participationem.'

39 SMet 1.1.Q2: 'Sed sicut non est perfecta scientia de aliquo causato sine scientia Primi, sic non est veritas alicuius causati veritas simpliciter; ipsum autem Primum est veritas simpliciter. Sic autem relinquitur quod una sola est veritas.'

40 SMet 7.4.E3 (S, fol. 95va): 'Consequenter distinguit ens, dicens quod ens dicitur multipliciter, non tamen aequivoce sed analogice; ens enim dicitur de una natura primo <natura primo] prima S $>$, ut de substantia, et de aliis per posterius, ut de accidentibus, et hoc propter aliquam attributionem quam habent ad substantiam. Unde ista multiplicitas non est pura aequivocatio.'

41 Averroes, In Metaph. 4.2, Venice, 1562, 8: fol. 65rb-66rb. See also E. Jennifer Ashworth, 'Analogy and Equivocation in Thirteenth-Century Logic: Aquinas in Context,' Mediaeval Studies 54 (1992), pp. 94-135. 
Rufus proceeds to distinguish four different kinds of names: simply univocal, simply equivocal, analogous (analogus), and multiply-said. They are distinguished in terms of the spoken sound (vox), the thing or nature, and the account (ratio) or notion (intentio) corresponding to the thing. With a simply univocal name there is one spoken sound, one nature, and one account. With a simply equivocal name, there is one spoken sound, more than one nature, and more than one account. With an analogous name, there is one spoken sound, more than one nature, but only one account. Finally, with a multiply-said name, there is one spoken sound, one nature, but more than one account. ${ }^{42}$

Rufus' notion here of a name said multiply (multipliciter) should not be confused with that of an analogous name (nomen analogum). As his definitions indicate, these are not the same thing. By an analogous name Rufus appears to have in mind what is called the analogy of proportionality, ${ }^{43}$ a notion of analogy involving the comparison of two relationships that plays a relatively peripheral role in medieval treatments of analogy. By contrast, it is the different notion of what is said analogically or multiply that applies to the names 'entity' and 'true', where there is one spoken sound, one thing or nature, but more than one account or notion.

Rufus does not explain how the spoken sound (vox), the thing or nature, and the ratio or intentio relate to the name (nomen). Probably he understood a name as it was standardly defined as a spoken sound (vox) conventionally endowed with signification. ${ }^{44}$ As for the res or nature and the ratio or intentio, in similar treatments of multiply-said names by other authors in the mid-13th century, the thing (res) signified is dis-

42 SMet 7.4.N2 (S, fol. 95va): 'Et nota differentiam inter nomen analogum <analogicum S> et multipliciter dictum et nomen simpliciter aequivocum et simpliciter univocum. Et est talis: Illud nomen est simpliciter univocum quando vox est una, et natura sive res una, et ratio sive intentio correspondens rei una. Illud autem est nomen simpliciter aequivocum quando vox est una, nec res sive natura una, nec intentio sive ratio correspondens ei. Illud autem est nomen analogum quando vox est una, et ratio sive intentio una, res sive natura cui respondet ratio non una, ut "totum” in continuis et discretis. Est enim vox huius nominis "totum” una hinc inde, et similiter ratio sive intentio, quia haec est ratio "aggregatum ex partibus”, res autem sive natura diversa; unitas enim aliud est a puncto, et numerus a magnitudine. Nomen autem multipliciter dictum est quando vox est una, res autem sive natura una, ratio autem sive intentio non una, ut hoc nomen "ens".' See also SPar 1.29 (V, fol. 74ra), where in place of the ratio or intentio Rufus speaks of what is connoted: 'Nomen differenter accipi potest esse tripliciter. Aut quantum ad suppositum, et hoc non inducit aliquam multiplicitatem. Aut quantum ad significatum, et hoc inducit aequivocationem. Aut quantum ad connotatum, et hoc inducit multiplicitatem secundum analogiam.'

43 As Silvia Donati points out in 'English Commentaries Before Scotus: A Case Study: The Discussion on the Unity of Being,' in A Companion to the Latin Medieval Commentaries on Aristotle's Metaphysics, ed. Gabriele Galluzzo and Fabrizio Amerini (Leiden; Boston: Brill, 2013), pp. 137-207, at p. 150. See also Ashworth, ‘Analogy and Equivocation,’ pp. 98-100.

44 More particularly, a name is defined by William of Sherwood, closely following Aristotle's account in De interpretatione 2 as translated by Boethius, as 'vox significativa ad placitum, sine tempore, cuius nulla pars separata aliquid significat, finita, recta’ (Introductiones in logicam, ed. Lohr et al., p. 223). 
tinguished from the intentiones or modi, and it would seem that by res or natura Rufus too means a thing or nature signified. ${ }^{45}$

Thus in the case of the name 'entity', Rufus remarks that the spoken sound is one and the nature is one, namely substance. Yet the ratio of the name 'entity' is diverse, 'for one sort of entity exists in its own right, and one does not.' Wherever the name 'entity' is said, substance is thought of - the nature predicated - but how it is thought of differs depending on the items of which 'entity' is predicated. When it is predicated of a substance, just substance is thought of. But when it is predicated of an accident a relationship to substance is thought of, one indicated when we say an accident is strictly speaking not a substance, but, using 'substantia' in an oblique case, of a substance, and so the account (ratio) is different. ${ }^{46}$ The predication of 'entity' of an accident is an extended use of 'entity'. Therefore, while it is not incorrect to say that accidents are entities, any more than, to use another example of a word said multiply, to say that urine is healthy, we must bear in mind that these are not direct predications of the natures in question (substance or health) signified by the names 'entity' and 'healthy'.

Regarding truth, in SMet Rufus presents the point that the concrete name 'true' is multiply said as a reason for holding that there is just one truth (veritas). ${ }^{47}$ His thought seems to be that since the concrete name 'true' can only be said in a primary sense of one thing, namely of the First, there will likewise only be one truth in a primary sense, since, as we've also seen York note, concrete and abstract names coapply in the case of God..$^{48}$ So if God is the one true thing, he is also the one truth.

45 Thus, Lambert of Auxerre says that an analogous term (his terminology for what is said multiply) such as 'entity' signifies one thing (unum) but under different notions (intentiones); Logica, ed. Franco Alessio (Florence: La Nuova Italia, 1971), p. 149. Peter of Spain describes the type of equivocation in question using the example, drawn from Aristotle, of sanus (healthy), distinguishing the thing signified, the health of an animal, from the different ways (modi) it is signified in application to things such as urine, medicine, and so forth; Tractatus, ed. de Rijk, pp. 98-99. Rufus himself developed a very complex theory of signification in SMet, as Rega Wood shows in 'Appellation, Signification, \& Universal Names According to Richard Rufus (d. circa 1259),' The Modern Schoolman 86 (20082009), pp. 65-122.

46 Rufus, SMet 7.4.N2 (S, fol. 95va): 'Est enim vox una et natura una, quia substantia; de nullo enim alio praedicatur ens directe. Unde Aristoteles: Accidentia non <non vel forsan: vero S> sunt entia, sed entis. Unde ubicumque dicitur ens, ibi intelligitur substantia, sive oblique sive recte. Ratio autem huius nominis “ens” est diversa; ens enim dicitur quoddam per se exsistens et quoddam non.'

47 Possibly in this regard Averroes had influenced Rufus' treatment of truth. As Richard Taylor has informed me, in his commentary on Metaphysics 2 (comment 4) Averroes writes: 'Omnia enim entia non acquirunt esse et veritatem nisi ab ista causa [prima]. Est igitur tantum ens per se et verum per se, et omnia entia et vera per esse et veritatem eius;' see In Aristotelis librum II ( $\alpha$ ) Metaphysicorum Commentarius, ed. Gion Darms (Freiburg: Paulusverlag Freiburg Schweiz, 1966), p. 59. However, there is no express reference to this passage in Rufus' treatment of this part of Aristotle's text.

48 See Rufus' Speculum animae (written at Oxford c.1245), where Rufus makes this last point and holds that God is predicated of creatures when they are called true or just: 'Nonne igitur tibi videtur de veritate quae una tantum est, et Deus est, qua omnia vera dicuntur vera, scilicet quod ipsa veritas quae Deus est, ut probat Beatus Augustinus, de omnibus veris praedicetur? Et similiter de iustitia idem Augustinus probat quod eadem sit et unica, et quae Deus est, qua omnia iusta dicuntur 
The First cause is true (verum), and caused things are true. Therefore this name 'true' is said of the First cause and of caused things. Either therefore it is said equivocally, or univocally, or multiply. ${ }^{49}$ Not univocally, because nothing is said purely univocally of the creator and creatures. Not equivocally, because then there would be no ordering or implication between 'true' said of the First himself and [said] of these things; in the same way nor [would this be the case with] good, if it were said equivocally. But there in fact is an ordering; therefore etc. Therefore it will be said multiply. But a name said multiply of many things primarily belongs to one and is imposed on others derivatively, namely on account of some relationships they have to that primary [thing to which it belongs]. And wherever such a name is predicated, that nature is predicated for which it is primarily imposed, though sometimes [that nature is predicated] directly, and sometimes obliquely. If this is so, then since 'true' belongs to the First, it will sometimes be predicated directly, namely when it is predicated of the First, and of other things obliquely. Therefore there is only one true item (verum) $)^{50}$

Rufus is claiming that the nature for which the name 'true' is primarily imposed is predicated whenever this name is predicated. But that nature is predicated directly only when it is predicated of the first cause, God; otherwise, it is predicated indirectly or obliquely. Since it is only predicated directly of one thing, when other things are said to be true, what is being said is that they stand in some sort of relationship to the nature predicated. It cannot be directly said of any other true item that it is true. Although Rufus does not expressly say what this nature is, though it is in fact identical with the First, we will see him hint in SOx that it is, as York holds, adequation.

An important difference between Rufus' treatment of 'true' and his treatment of 'entity' in SMet is that as SMet treats it, 'entity' can be directly predicated of many substances. This difference reflects the fact that a name can be said analogically

iusta; et hoc de omnibus creaturis iustis praedicatur, scilicet concretive. Quanta benignitas, quanta largitas quam ut Creator praedicari se permittat aliquo modo, scilicet concretivo, et per aliqua nomina ipsum signantia, qualitatem scilicet designantia! Sed tale nomen de ipso Creatore praedicatur, scilicet concretive et abstractive, nam essentialiter. De creaturis vero solum concretive - hoc est, per participationem, et non essentialiter. Non est enim creaturae hoc esse iustum [est], hoc esse quod est esse verum. Et ideo nulla creatura essentialiter et abstractive, sed per participationem et concretive dicitur iustum et verum;' Rufus, Speculum animae, ed. Rega Wood in Matthew X. Etchemendy and Rega Wood, 'Speculum animae: Richard Rufus on Perception and Cognition,' Franciscan Studies 69 (2011), p. 129 in pp. 53-140.

49 It may be noted that Rufus here makes no mention of the category of the analogous name (nomen analogum) mentioned elsewhere in SMet.

50 SMet 1.1.Q1: 'Prima causa verum est, et causata vera sunt. Hoc igitur nomen "verum" dicitur de prima causa et de causatis. Aut ergo aequivoce aut univoce aut multipliciter dictum. Univoce non, quia nihil pure univoce dicitur de creatore et creaturis. Aequivoce non, quia sic non esset ordinatio nec consequentia inter verum dictum de Primo et de istis rebus; eodem modo nec bonum, si aequivoce diceretur; nunc autem est ordinatio; ergo etc. Ergo multipliciter dicetur. Sed nomen multipliciter dictum de multis primo uni convenit et imponitur aliis consequenter, scilicet propter aliquas attributiones ipsorum ad primum. Et ubicumque tale nomen praedicatur, praedicatur illa natura cui primo imponitur, sed aliquando recte, aliquando oblique. Si hoc ita est, cum "verum" conveniat Primo, praedicabitur aliquando directe, scilicet cum de Ipso praedicatur, et de aliis oblique. Igitur unum solum verum est.' 
over two dimensions. SMet's treatment of 'entity' concerns its application across the categories. It is predicated directly of substances, but obliquely or indirectly of accidents. But in SMet Rufus speaks about 'true' as a name said analogically as it applies to God and creatures, considering the applicability of this name to God and creatures rather than across the categories. In this case he holds that it can only be primarily and directly predicated of one thing, God.

But 'entity' too is a name applying to God and creatures, and in his Sentences commentaries, where he is working as a theologian, Rufus also treats 'entity' as a name multiply said of God and creatures and takes it to be akin to 'true'. The account of 'entity' given in SMet should be understood in terms of the limited perspective of the philosopher. ${ }^{51}$

In SOx Rufus also expands a little on how he understands the relationships (attributiones) to God of the things of which 'entity' is predicated derivatively or indirectly. In analogy, he holds, there is always one primary and principal item signified, and the name in question applies to other things on account of their relationships to that one. These other things participate in the primary thing signified and it is thought of in their names, though obliquely, not directly. Indeed, Rufus holds that the unqualified entity, God, is understood obliquely in the name of every creature..$^{52}$

Rufus equates the notion of participation here with that of likeness, suggesting the relationship involved in calling created things entities is that of likeness, and that all names said of both God and creatures, including 'good', 'just' and 'true', as said of creatures involve some sort of likeness to God. Rufus calls this likeness an imitative likeness (imitatoria similitudo), an uncommon terminology probably drawn from Grosseteste's De libero arbitrio or Hexaëmeron, works Rufus employed in his lectures on the Sentences. ${ }^{53}$

51 According to Rufus the first philosopher as such is concerned only with caused things, and hence not with the first cause. See SMet 5.8.Q2D: 'Ad aliud quod causa prima non continetur sub significatione "entis per se" nec "substantiae"; non enim comprehendit primus philosophus sub "ente" et "substantia" nisi causata, quia non alia nisi quae sunt sub genere, et ideo sub modis "entis" et "substantiae" non comprehenditur causa prima.'

52 SOx 1.2I (B, fol. 22va-vb): 'In analogia est semper unum significatum primum et principale, et propter aliquas attributiones aliorum ad illud conceditur nomen illis aliis, et illud primum ab omnibus aliis participatur et in eorum nominibus intelligitur, sed oblique, non in recto. Verbi gratia, in definitione hominis picti accipitur vivus. Est enim homo pictus imago hominis vivi, et est haec definitio hominis picti. Similiter dico in nomine cuiuslibet creaturae intelligitur simpliciter ens, scilicet Deus, sed oblique. Et forte bene et verissime sic definiretur quaelibet creatura. Lignum est entis talis similitudo, homo talis, asinus talis, si quis veraciter sciret harum similitudinum distinctiones exprimere.'

53 SOx 1.2I (B, fol. 22vb): 'Quod dixi de communitate huius nominis “ens”, puto simile iudicium de omnibus aliis dictis de Deo et creaturis, sicut de 'bono'. Non enim est creatura bona nisi quia qualisqualis similitudo boni, nec iusta, nec vera. Similiter caritas de Deo dicta et de dilectione hominis vel angeli. Nec est forte dilectio angeli caritas vel dilectio nisi quia vere et simpliciter caritatis qualis qualis imitatoria similitude.' For Grosseteste's use of the expression 'imitatoria similitudo' see below, n. 57 . 
Now when he wrote SOx Rufus had before him Grosseteste's De veritate, and he expressly paraphrases Grosseteste's response to the question of the unicity of truth, and Rufus' remarks here throw a little more light on his own view. Though he does not mention Grosseteste's view that 'truths' in application to creatures supposits or stands for many created truths, Rufus correctly holds that the many created truths Grosseteste speaks of are the adequations of things to the eternal Word. Rufus treats these adequations as likenesses to the eternal Word. And at one point in laying out Grosseteste's view, he says that these thinkers - that is, Grosseteste - attest with him that the truth of a thing is its adequation to itself in the Word..$^{54}$ Rufus thus seems to intimate that Grosseteste's view does not really differ from his own, once we see that what Grosseteste expresses in terms of adequation, he is expressing in terms of participation, understood in terms of likeness: the adequation of a thing to its reason in the Word just is its likeness of itself in the Word. ${ }^{55}$

Of course, Grosseteste says that there are many truths, since there are the many adequations of creatures to the Word. But Rufus is prepared to say there are many truths too, provided we bear in mind that the name 'truth' is being used in an extended sense of creatures, and is only applicable in a strict sense to God. This is clearly stated in SOx and then in SPar, his last word on the subject, where Rufus notes that the names 'entity' and 'truth' both apply to God alone in a strict sense, and that truth is said of creatures by analogy and by extension. In particular, "truth" and "true" said of creatures express some sort of likeness of the unqualifiedly first truth. Hence created truth is called truth by imitation, and is a trace of the first truth. ${ }^{56}$

54 SOx pr. H (B, fol.10va): 'In hac tanta difficultate respondent quidam, concedentes quod sit veritas creata et increata, et quod sunt veritates creatae etiam multae. (...) Volunt etiam quod veritas cuiuslibet causati sit adaequatio et conformitas sui ad ipsum Verbum Dei, quia tunc dicitur verus homo cum conformatur homini exsistenti in aeterno Verbo, similiter verus lapis cum conformatur lapidi exsistenti in aeterno Verbo, et ita de aliis. Sed etiam secundum istum modum de necessitate erunt plures veritates causatae. Nam haec adaequatio lapidis sive conformitas quid est nisi eius qualisqualis similitudo ad ipsum Verbum aeternum? Haec autem similitudo non est natura media in qua assimilentur Verbum aeternum et lapis, sed est id idem quod ipse lapis. Hoc etiam ipsi mecum testantur, dicentes quod veritas rei est adaequatio eius ad se ipsam in aeterno Verbo. Haec autem adaequatio nihil aliud est nisi id quod exprimimus per definitionem cuiusque. Planum est igitur secundum istam viam quod erunt plures veritates et differentes. Addunt etiam quod cum duplex sit esse cuiuslibet causati, primum scilicet et secundum; primum esse in se secundum quod ipsum est, secundum esse, scilicet esse secundum quod comparatur ad finem suum. Dicunt ergo quod cum sic sit esse duplex cuiuslibet causati et utrumque esse sit veritas, quot sunt creaturae, non solum tot, sed duplo plures erunt veritates creatae. Sic ergo, secundum eos, manifestum est quod non omnis veritas est aeterna veritas.'

55 Where Rufus does go beyond Grosseteste is in identifying this adequation with what is expressed by a creature's definition. In Sapientiale 6.25 (ed. Scully, p. 376) York writes in a similar vein that 'ipsa essentia rei non est aliud essentialiter a sua adaequatione cum veritate prima.'

56 SOx pr. H (B, fol. 10va): 'Sine omni assertione dixerim quod Augustinus forte senserit in hoc nomine "veritatis" quod in aliis nominibus de Deo et creatura dictis, scilicet quod secundum analogiam sive secundum prius et posterius dicatur veritas, et quod proprie et principaliter et maxime dicta non est 


\section{Concluding Remarks}

It is clear from what I have said above that despite verbal differences between Grosseteste and York, on the one hand, and Rufus on the other, there are also similarities in the views they present. Are their views really that different then?

Apparently not. The differences do appear to be more verbal than substantive. In particular, both Grosseteste and York propose accounts of the predication of 'truth' of created things akin to Rufus' account. They all agree that in predicating 'truth' of a created thing we are expressing some sort of relationship of it to the supreme truth or Word, and that the term 'truth' only applies directly to the supreme truth itself. They all agree that there are many adequation relations of things to the supreme truth. Grosseteste and York think this sufficient reason to say there are many truths. Rufus takes this as sufficient ground to say that there are many truths too, but only in a qualified manner, since what makes 'truth' predicable of these relations is the fact that they imitate the supreme truth itself. Thus 'truth' is said multiply or analogically of God and creatures. But Grosseteste and York too hold that 'truth' is predicable of such relations because they are relations to the supreme truth. And so, the key difference seems to be that, having made this point, on which they agree with Rufus, they do not introduce the idea of analogy, but simply state that there are many truths, whereas Rufus introduces reference to analogy.

Even so, both Grosseteste and York are clearly committed elsewhere in their writings to denial of univocity in the application of names to both God and creatures. And so since 'truth' is applied to both, and is not purely equivocal, it is being used in some manner intermediate between these.

Now Grosseteste expressly denies that any names can be said univocally of God and creatures, and yet he holds that there are some names said in common of God and creatures that, although equivocal, are not purely equivocal. And in the case of names said in common of God and rational creatures, such as 'liberum arbitrium', Grosseteste holds such a name can be applied to the rational creature as well as to God because the rational creature is an imitative likeness (similitudo imitatoria)

nisi ipsum Verbum aeternum, accommodato tamen nomine et per extensionem accepto possit dici veritas creata, ita et sapientia, sic et bonitas.' SPar 1.8 (V, fol. 26rb): 'Sed sicut hoc nomen "ens” simpliciter et proprie dictum non convenit nisi Deo, sic et hoc nomen "veritas”. Et hoc intelligunt Augustinus et Anselmus, non quod nullo modo sint plures veritates, sed quod veritas per analogiam dicitur, et simpliciter et proprie nonnisi de Deo, per extensionem de creaturis. Unde dicit Anselmus, Monologion, capitulo 28, "Creata quia tam mutabiliter sunt, non immerito negantur simpliciter et absolute esse, et asseruntur fere non esse et vix esse." Similiter intelligendum est de veritate et vero, scilicet quod haec dicta "veritas" et "verum" de creaturis similitudinem qualemqualem dicunt veritatis simpliciter primae, unde veritas creata imitatione dicitur veritas et est vestigium aliquod veritatis primae.' 
of God - a terminology we have seen Rufus borrow. ${ }^{57}$ And as we noted above, Grosseteste holds that 'entity' (ens) and 'being' (esse) are said of God and creatures 'according to prior and posterior. ${ }^{25}$

Likewise, although York does not speak of analogy in his treatment of the unicity of truth, he hints at it at the end of the last passage I quoted from him, where he says the uncreated truth is truer than every other. And a little later in the Sapientiale, citing this very point in support, he uses the same terminology of names said multiply or analogically that we have seen in Rufus, expressly adopting a doctrine of analogy in respect of the name 'truth'. Thus, in Sapientiale 6.27 he writes that:

just as 'an entity' (ens) and 'entity' (entitas) are names said multiply, that is, analogically, so are 'true' and 'truth'. For otherwise one true thing would not be truer than another, which goes against Augustine in Soliloquies 2. Now the nature of things said multiply is that they are attributed to one nature and primary notion, which is partaken differently in the others. ${ }^{59}$

Therefore, York too, though expressly positing many truths, also is committed to the view that 'truth' is a name applying analogically to created truths and the supreme truth.

I have touched on just the tip of the iceberg in these remarks on the unicity of truth, focusing only on logical issues raised by our authors. A fuller treatment of their views on unicity would also need to examine much more closely the metaphysical background they are working with, which in the case of Rufus, and especially Grosseteste, is not an easy task given that they devote no question expressly to pertinent metaphysical issues. Even so, it is clear from this investigation that the treatments of unicity in these authors are intertwined. This I suspect will be found to be true for other important topics of their day - as it is, for example, regarding the complex debate over the eternal truths also treated by all three authors. We should expect much more light to be shed on their relations, and thereby on philosophical developments in England before c.1260, once the ongoing critical editions of works by Rufus and York are completed.

57 Grosseteste, On Free Decision, ed. Neil Lewis, Auctores Britannici Medii Aevi 29 (Oxford: Oxford University Press, 2017), p. 226; Hexaëmeron 8.1.2, ed. Richard C. Dales and Servus Gieben, Auctores Britannici Medii Aevi 6 (Oxford: Oxford University Press, 1982), pp. 217-18.

58 See above, n. 29.

59 York, Sapientiale 6.27, ed Scully, pp. 410-11: 'Sicut ens ita verum, sicut entitas ita veritas est nomen multipliciter, id est analogice dictum; aliter enim non esset verum vero verius, quod est contra Augustinum, Soliloquiorum II. Multipliciter autem dictorum natura est quod attribuantur uni naturae et intentioni primae, quae differenter participetur in aliis.' 